\title{
ENHANCED ADSORPTION CAPACITY OF PEANUT SHELL TOWARD RHODAMINE B VIA SODIUM DODECYL SULFATE MODIFICATION
}

\author{
Is Fatimah, Bonusa Nabila Huda, Ilmi Lucyawati Yusuf and Budi Hartono \\ Department of Chemistry, Universitas Islam Indonesia, Kampus Terpadu UII, Jl. Kaliurang Km \\ 14, Sleman, Yogyakarta, Indonesia, 55584 \\ *E-mail: isfatimah@uii.ac.id
}

\begin{abstract}
Batch and flow adsorption experiments of rhodamine B were carried out by using peanut shell (PS) and sodium dodecyl sulfate-modified peanut shell (SDS/PS) as adsorbents. The study was aimed to evaluate the effect of SDS modification on the physicochemical character of PS and the kinetics of adsorption and adsorption capacity of PS. Instrumental characterizations consist of scanning electron microscope (SEM), Fourier Transform-Infra Red (FTIR), Boehm titration and gas sorption analyses were performed for evaluation. The results showed that SDS modification enhances the specific surface area and pore distribution. Kinetics of adsorption, adsorption isotherm, the effect of temperature, and adsorption thermodynamics were studied. It was found that in general, SDS modification enhance the adsorption rate of $\mathrm{RhB}$, as well as affecting the adsorption kinetics. RhB adsorption over PS is fit to a pseudosecond-order model, while the adsorption over SDS/PS obeys Elovich kinetics model. Thermodynamic study of the adsorption kinetics was also conducted. Equilibrium study analyzed using the Langmuir, Freundlich, Temkin and Dubinin-Radushkevich (D-R) isotherms suggest that the adsorption data tend to obey D-R isotherm. The determined adsorption capacities of PS and SDS/PS are 133.146 and $236.699 \mathrm{meq} / \mathrm{g}$.
\end{abstract}

Keywords: Adsorption, Biosorbent, Peanut Shell, Adsorption isotherm

(C) RASĀYAN. All rights reserved

\section{INTRODUCTION}

Dye waste is one of the important problems in environmental cases since it leads toxic, odor and unaesthetic effect as released into water bodies. In another side, dye waste is produced in many industries such as textile, paint, and printing. In advance, in the scheme of the textile industry, Batik industries are also the dye waste producers that need technology to handle dye waste easy in practice. ${ }^{1-3}$ Many technologies and advanced techniques are developed for dye degradation for water treatment, such as ozonization, chemical oxidation and advanced oxidation process. However, those techniques are not feasible for small industrial scale like the home-industrial scale of Batik. Low cost, easy and more applicable methods are required for either environmental sustainability or Batik sustainability itself. Simple method can be adopted for this is mild chemical oxidation method combined with adsorption technique. Adsorption method is well-known and effective technology has been reported to be a feasible method for dye waste treatment. Low-cost method of adsorption can be achieved by the utilization of low-cost adsorbent such as the utilization of agricultural waste., ${ }^{4,5}$ Many studies concerned on the utilization of animal and agro waste for dye removal from water showed the contribution of the biosorption process to be developed and intensively studied for low-cost adsorption applications. ${ }^{6-9}$

Peanut shell is a type of abundant agricultural waste in Indonesia. It is about 600-730 kton of peanut produced annually from 2010-2015 in Indonesia, and the peanut shell left is about $25 \%$ of these amount. ${ }^{10}$ Due to its chemical structure, the peanut shell is a potential biosorbent. Its structure consists of cellulose and other carbon polymer having the ability to adsorb pollutant molecules such as dye molecules. Previous researches revealed that peanut shell has the potency to be used for adsorption of selected metals

Rasayan J. Chem., 11(3), 1166-1176(2018)

http://dx.doi.org/10.31788/RJC.2018.1134021

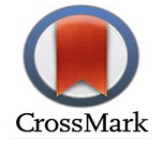


RASĀYAN J. Chem.

Vol. 11 | No. 3 |1166 - 1176 | July - September | 2018

such as $\mathrm{Hg}, \mathrm{Pb}$ and $\mathrm{Cu}$ and also dye molecule of eriochrome black $\mathrm{T}$ (EBT), methylene blue. ${ }^{11-13}$ The utilization of peanut shell consists of its raw form and an activated carbon as listed in Table-1.

Table-1: Utilization of Peanut Shell for Adsorption

\begin{tabular}{|c|c|c|c|}
\hline Form & Adsorbate & Result & Reference \\
\hline Peanut shell & Ericohrome black T & $\begin{array}{l}\text { Adsorption of EBT obeys Langmuir isotherm with } \\
\text { adsorption capacity of } 48.81 \mathrm{mg}^{-\mathrm{g}^{-1}}\end{array}$ & 11 \\
\hline Peanut shell & $\mathrm{Pb}$ (II) & $\begin{array}{l}\text { The adsorption capacity of the sorbent for } \mathrm{Pb}(\mathrm{II}) \text { was } \\
\text { calculated from the Langmuir isotherm model and found to } \\
\text { be } 7.1 \mathrm{mg} \text { - } 1 \text { at } \mathrm{pH} 4\end{array}$ & 13 \\
\hline Peanut shell & $\mathrm{Cu}(\mathrm{II})$ & $\begin{array}{l}\text { The adsorption } \\
\text { obeyed Langmuir adsorption isotherm. } \\
\text { Quantitative removal of } \mathrm{Cu}(\mathrm{I} 1) \text { from a solution containing } \\
20 \mathrm{mg} / \mathrm{L} \mathrm{Cu}(\mathrm{II}) \text { by } 0.9 \mathrm{~g} \mathrm{PHC} \text { per liter was observed in the } \\
\text { pH range of } 4.0 \text { to } 10.0\end{array}$ & 14 \\
\hline $\begin{array}{l}\text { Activated } \\
\text { carbon }\end{array}$ & $\mathrm{Pb}$ (II) & $\begin{array}{l}\text { Adsorption fit to the Langmuir adsorption model. } \\
\text { Adsorption capacity of } \mathrm{Pb} 2+\text { reach } 35.5 \mathrm{mg} \cdot \mathrm{g}^{-1}\end{array}$ & 15 \\
\hline $\begin{array}{l}\text { Activated } \\
\text { carbon }\end{array}$ & $\begin{array}{l}\text { Methylene blue } \\
(\mathrm{MB})\end{array}$ & $\begin{array}{l}\text { The adsorbent is effective adsorbent to remove Methylene } \\
\text { blue dye from an aqueous solution that accompanied with } \\
\text { significant microbiostatic activity }\end{array}$ & 16 \\
\hline $\begin{array}{l}\text { Activated } \\
\text { carbon derived } \\
\text { from } \\
\text { microwave- } \\
\text { pyrolisis }\end{array}$ & $\begin{array}{lrr}\text { Direct } & \text { Black } & 38 \\
\text { (DB38) } & & \text { and } \\
\text { Reactive } & \text { Red } & 141 \\
\text { (RR141) dyes } & \end{array}$ & $\begin{array}{l}\text { The Sips isotherm model was adequate to represent the } \\
\text { adsorption of DB38 and RR } 141 \text { on the MW-P with } \\
\text { adsorption capacities of } 110.6 \text { and } 284.5 \text { mg g } \mathrm{g}^{-1} \text {, } \\
\text { respectively }\end{array}$ & 17 \\
\hline $\begin{array}{l}\text { Activated } \\
\text { carbon }\end{array}$ & Methomyl & $\begin{array}{l}\text { Equilibrium adsorption data fitted the Langmuir adsorption } \\
\text { isotherm with the recovery }>95 \%\end{array}$ & 18 \\
\hline $\begin{array}{l}\text { Amine- } \\
\text { modified } \\
\text { peanut shell }\end{array}$ & direct red (DR80) & $\begin{array}{l}\text { Tetraethylenepentamine (TEPA), triethylenetetramine } \\
\text { (TETA), Diethylenetriamine (DETA) modified peanut shell } \\
\text { have enhanced adsorption capacity towards DR80 with } \\
\text { optimum adsorption capacity of } 690.18,657.55 \text { and } 588.56 \\
\mathrm{mg} / \mathrm{g}\end{array}$ & 19 \\
\hline
\end{tabular}

It is noticed that instead of carbonization of peanut shell, the use of raw form gives similar adsorption capacity in some cases. As many types of research in adsorption using biosorbent, some important parameters to be noted for those applications of peanut shell as adsorbent are $\mathrm{pH}$, adsorbent dosage, and temperature. In another scheme, enhancement for adsorption capacity of peanut shell was attempted by base, acid and surfactant modification of the surface.

With a different surface mechanism, surfactant modification to biosorbent surface exhibits significant enhancement refers to the change of chemical bonding and interaction between the adsorbate and the adsorbent during the adsorption process. The presence of a hydrophobic site of the anchored surfactant contributes to force the surface interaction between adsorbent and molecule via polarity and reduced interaction energy. Previous investigations reported that surfactant-modified biomass enhanced adsorption capacity, for example in cetyl trimethyl ammonium bromide-modified coconut coir for $\mathrm{Cr}(\mathrm{VI})$ adsorption and other lignocellulosic materials. ${ }^{20-22}$ Refer to these backgrounds and potency of peanut shell, this work is focusing on the utilization of peanut shell and the enhancement for the adsorption of dye over surfactant modification. Specifically, rhodamine B was used as dye model with respect to its vast utilization in Batik's industries. For surface modification, sodium dodecyl sulfate (SDS) was used. Effect of SDS modification on surface properties and adsorption capacity towards $\mathrm{RhB}$ of peanut shell was aimed in this study.

\section{EXPERIMENTAL}

\section{Materials}

The main material for adsorbent preparation of peanut shell was obtained from a local market in Sleman District, Yogyakarta. Chemicals consist of rhodamine B (RhB), $\mathrm{HCl}, \mathrm{NaOH}, \mathrm{Na}_{2} \mathrm{CO}_{3}, \mathrm{NaHCO}_{3}$, sodium 
RASĀYAN J. Chem.

Vol. 11 | No. 3 |1166 - 1176 | July - September | 2018

dodecylsulfate (SDS), phenolphthalein and methyl orange indicators were purchased from Merck (Germany), and used as received.

\section{Methods}

Instrumental analysis of scanning electron microscope-energy dispersive X-ray (SEM-EDX) JEOL JX, UV Visible spectrophotometer of HITACHI U-2010, and Quantachrome gas sorption analyzer were employed for characterization and kinetics study of the adsorption.

Boehm analysis was conducted to evaluate the functional groups of the adsorbents. The analysis consists of the number of the basic sites, a total of acid sites, carboxylic acid, lactone, and phenolic groups. The total basic site was calculated from the amount of $\mathrm{HCl}$ that reacted with the adsorbents, while the various acidic groups were derived using the amount of $\mathrm{NaOH}$ required to neutralizes carboxyl, lactone and phenolic groups, $\mathrm{Na}_{2} \mathrm{CO}_{3}$ neutralizes carboxyl and lactone. The $\mathrm{NaHCO}_{3}$ neutralizes only carboxyl groups. The excess of base or acid was then determined by back titration using $\mathrm{NaOH}(0.10 \mathrm{M})$ and $\mathrm{HCl}$ $(0.10 \mathrm{M})$ solutions.

\section{Preparation and Characterization of SDS-Modified Peanut Shell (SDS/PS)}

Peanut shell was washed and dried before crashed and sieved in 150 mesh in size. For modification, the powder was mixed with $0.25 \%$ of SDS solution followed by stirring for overnight. The material of SDS/PS was then obtained by filtering the mixture and drying the powder. Physicochemical characterization of PS and SDS/PS was performed by Boehm test, SEM-EDX, FTIR and gas sorption analyses. Boehm test was conducted for the evaluation of lactone, phenolic and carboxylic determination based on acid-base titration method refer to previous literature..$^{23,24}$

\section{Adsorption Experiment}

The adsorption experiments were carried out in a batch system. The adsorbent was mixed with RhB solution under stirring for a certain time. The concentration of $\mathrm{RhB}$ after adsorption was analyzed by colorimetric method using UV-Visible spectrophotometry. Varied parameters in the adsorption experiments were $\mathrm{RhB}$ concentration, time of adsorption, temperature, and $\mathrm{pH}$ of the solution.

\section{RESULTS AND DISCUSSION}

The identification and quantification of the surface oxygen groups in the PS sample were performed by Boehm titration and the parameters are listed in Table- 2 .

Table-2: Functional Group Analysis of PS and SDS/PS

\begin{tabular}{c|c|c}
\hline \multirow{2}{*}{ Chemical Parameter } & \multicolumn{2}{|c}{ Value (meq/g) } \\
\cline { 2 - 3 } & PS & SDS/PS \\
\hline Carboxylic (-COOH) & 1.627 & 1.560 \\
\hline Lactone (-COO-) & 1.637 & 1.580 \\
\hline Phenolic (-OH) & 1.665 & 1.632 \\
\hline Total acid function & 4.929 & 4.772 \\
\hline Total basic function & 1.297 & 1.291 \\
\hline Cation exchange capacity & 6.226 & 6.053 \\
\hline
\end{tabular}

From the chemical parameters obtained it is concluded that the PS contains higher total acid function compared with the basic function along with the high content of carboxylic acid, lactone, and phenolic functional group. These surfaces functional groups are theoretically determined as driving force for the surface interaction with a functional group of $\mathrm{RhB}$ dye molecule via hydrogen bonding and electron pair mechanisms. The amount of almost all functional groups is not significantly changed by SDS modification but in general, the values from SDS/PS are slightly lower than in PS. These lower values are probably come from the coverage of surfactant structure which containing a hydrophobic chain.

Physicochemical characterization of PS and SDS/PS was studied by using surface morphology and elemental analyses using SEM-EDX, Boehm test, FTIR analysis and surface area analysis. Surface 
RASĀYAN J. Chem.

Vol. 11 | No. 3 |1166 - 1176 | July - September | 2018

morphology and result from EDX analyses are depicted in Fig.-1, and chemical composition from EDX analysis is presented in Table 3. The change in surface roughness and appearance is identified in that SDS/PS gives flaky structure compared to PS along with the change in chemical composition as reflected by EDX spectra and also chemical composition. The additional SDS in the modification contributes to increasing carbon content. Beside carbon as a dominant element in PS, $\mathrm{Al}, \mathrm{Si}, \mathrm{K} \mathrm{Ca}$, and $\mathrm{Na}$ is detected as minor components.
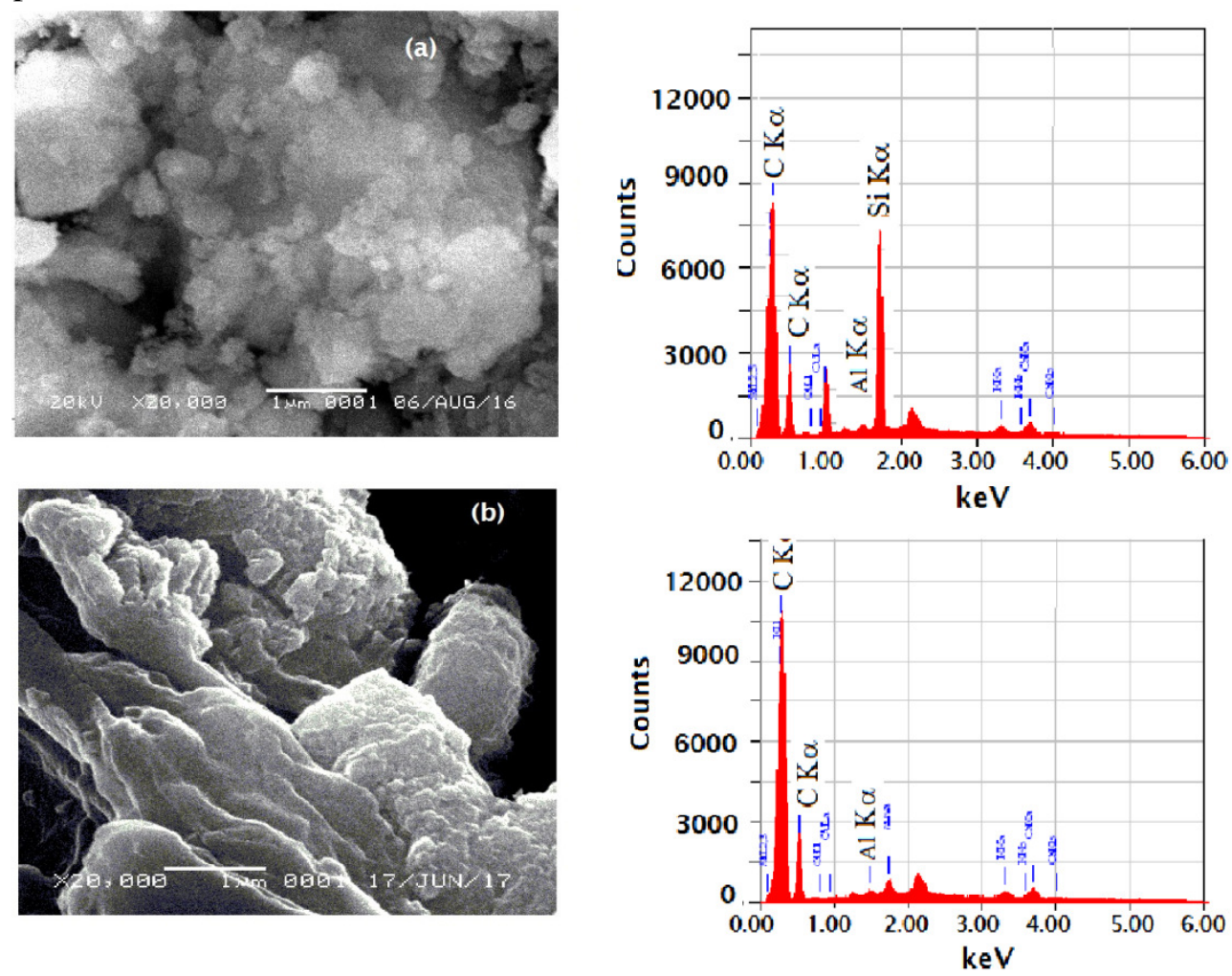

Fig.-1: SEM-EDX of (a) PS (b) SDS/PS

Table-3: Elemental Analysis Result of PS and SDS/PS

\begin{tabular}{c|c|c}
\hline Component (\%wt.) & PS & SDS/PS \\
\hline $\mathrm{C}$ & 50.79 & 85.25 \\
\hline $\mathrm{Si}$ & 12.43 & 1.16 \\
\hline $\mathrm{Al}$ & 0.92 & 0.86 \\
\hline $\mathrm{K}$ & 3.31 & 1.58 \\
\hline $\mathrm{Na}$ & 5.81 & n.d \\
\hline $\mathrm{Ca}$ & n.d & 3.69 \\
\hline $\mathrm{Cu}$ & 1.06 & 3.48 \\
\hline \multicolumn{2}{|c}{}
\end{tabular}

The flaky surface of SDS/PS is in line with the pore distribution profile obtained from gas sorption analysis presented in Fig.-2.

The more opening surface of SDS/PS is associated with the surfactant effect to lignocellulose surface contribute to the increasing pore volume at all range of pore radius. Based on adsorption/desorption data, specific surface area, pore volume and a pore radius of materials are tabulated in Table- 4 .

Table-4: Surface Parameters of Adsorbent

\begin{tabular}{l|l|l}
\hline Surface parameter & PS & SDS/PS \\
\hline Pore Volume $(\mathrm{cc} / \mathrm{g})$ & $1.535 \times 10^{-2}$ & $4.357 \times 10^{-2}$ \\
\hline Surface area $\left(\mathrm{m}^{2} / \mathrm{g}\right)$ & 7.341 & 11.023 \\
\hline Pore Radius $(\AA)$ & $10.9 \quad 1169$ & 11.08 \\
\hline
\end{tabular}


RASĀYAN $J$. Chem.

Vol. 11 | No. 3 |1166 - 1176 | July - September | 2018

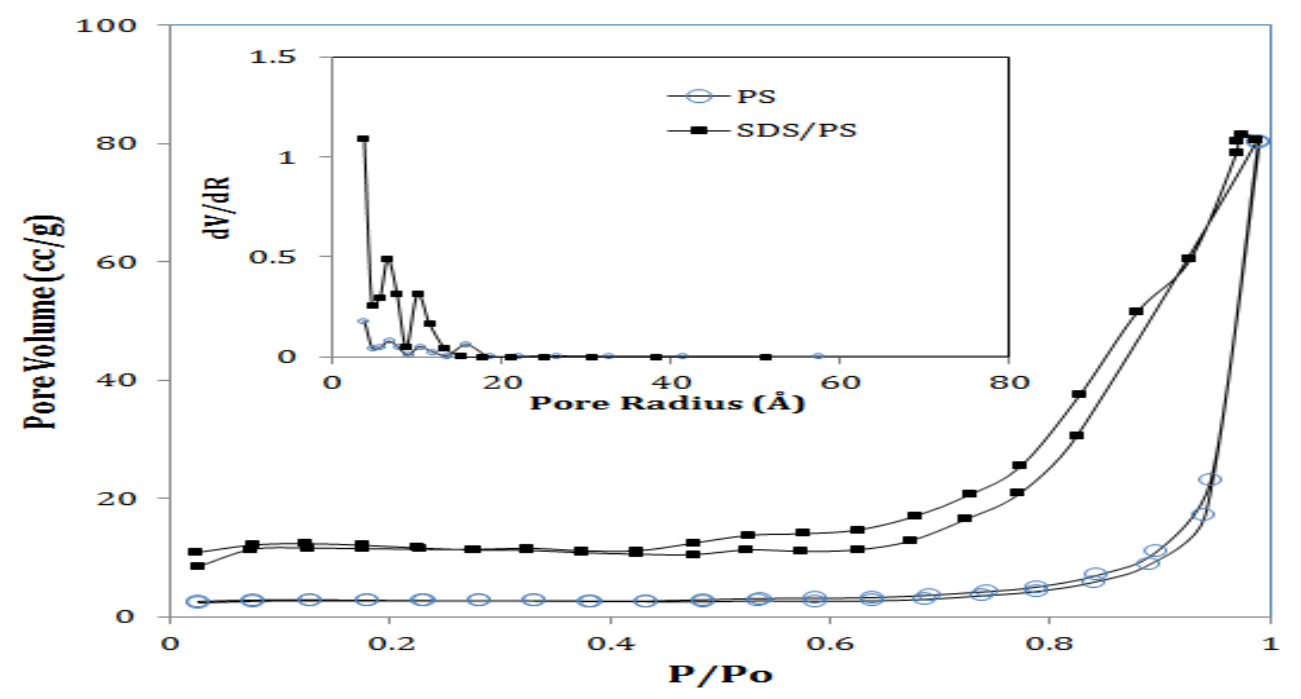

Fig.-2: Adsorption-Desorption Pattern and Pore Distribution of Materials

Effect of SDS modification to PS surface functional groups is identified from FTIR spectra as it displayed in Fig.-3.

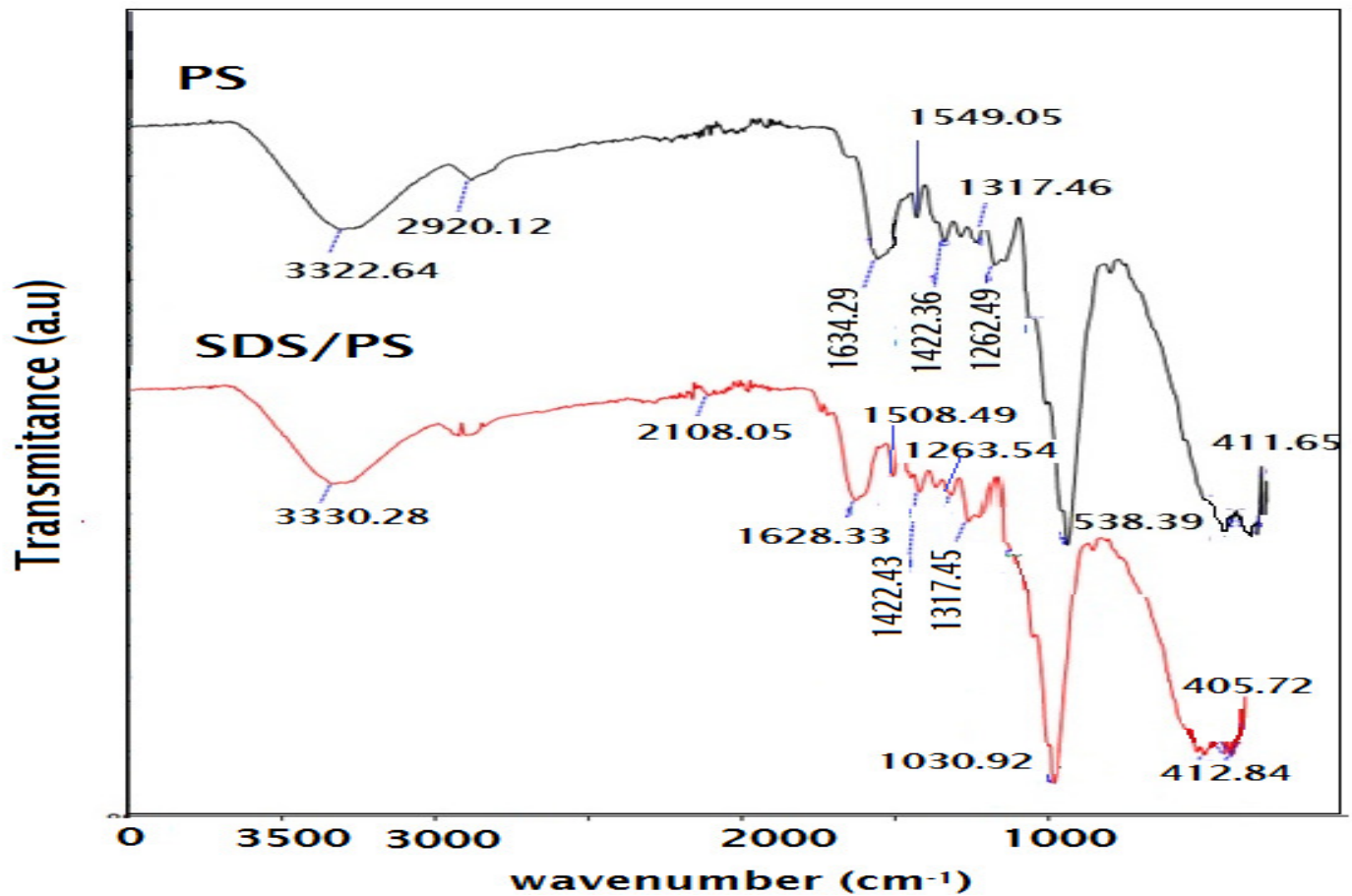

Fig.-3: FTIR Spectra of Materials

The insignificant difference of the spectra from PS and SDS/PS is observed. Both samples show an absorption spectrum at around $3332 \mathrm{~cm}^{-1}, 2920 \mathrm{~cm}^{-1}$ and $1628-1634 \mathrm{~cm}^{-1}$ corresponding to $\mathrm{O}-\mathrm{H}, \mathrm{C}-\mathrm{H}$, and $\mathrm{C}-\mathrm{C}$ vibrations, respectively. Other spectra at around $1422 \mathrm{~cm}^{-1}$ are attributed to the symmetric stretching of $\mathrm{CH}_{3}$ and other supporting spectra at fingerprint region $\left(<900 \mathrm{~cm}^{-1}\right)$. Effect of SDS attachment on PS surface is identified from the shift of spectrum at around $3332 \mathrm{~cm}^{-1}$ in PS into $330 \mathrm{~cm}^{-1}$ and identified spectrum reflecting more $\mathrm{C}-\mathrm{H}$ bands at $2108 \mathrm{~cm}^{-1}$. However, the comparison gives no spectrum representing sulfonate functional group at around $1129 \mathrm{~cm}^{-1}$ which possibly due to the very low concentration of SDS attached $(2.5 \% \mathrm{wt} \text {. })^{25}$.

Kinetics of RhB adsorption over PS and SDS/PS is presented in Fig.-4. The kinetics data are obtained by adsorption experiment using $2 \mathrm{~g}$ of adsorbent in $600 \mathrm{~mL}$ of $\mathrm{RhB}$ solution with the concentration of $2 \mathrm{ppm}$. 
RASĀYAN J. Chem.

Vol. 11 | No. 3 |1166 - 1176 | July - September | 2018

Overall from the comparison, the higher adsorption capability is demonstrated by SDS/PS. The reduction of about $75 \% \mathrm{RhB}$ concentration is achieved after 60 minutes of adsorption over SDS/PS, meanwhile, the reduction reached about $60 \%$ for the same time over PS. In order to evaluate the effect of surfactant modification on the kinetics of adsorption, kinetics study to the data was determined by modeling the data with the pseudo-first order, pseudo-second order, and Elovich model. The equations are (1-2):

Pseudo-first order : $\ln \left[q_{e}-q_{t}\right]=\ln q_{e}-k_{1} t$

Pseudo-second order: $\frac{t}{q_{t}}=\frac{t}{q_{e}}+\frac{1}{k_{2} q_{e}^{2}}$

Where $q_{e}, q_{t}, k_{1}, k_{2}$ and $\mathrm{t}$ are the amount of $\mathrm{RhB}$ in equilibrium, amount of adsorbed $\mathrm{RhB}$, kinetics constant of pseudo-first order kinetics, kinetics constant of pseudo-second-order kinetics, and time of adsorption, respectively. Meanwhile, Elovich equation is as follow (3):

$q_{t}=\frac{\ln a_{E} b_{E}}{b_{E}}+\frac{1}{b_{E}} \ln t$

Where $q_{t}$ is adsorbed $\mathrm{RhB}, a_{E}$ is the parameter related to initial adsorption rate $(\mathrm{mg} / \mathrm{g} \mathrm{min}), b_{E}$ is the constant related to the surface coverage and activation energy for chemisorption $(\mathrm{g} / \mathrm{mg})$, and $\mathrm{t}$ is a time of adsorption.

Refer to the calculation listed in Table-5, it is found that RhB adsorption using PS adsorbent obey pseudo-second-order kinetics, meanwhile, the adsorption over SDS/PS is fit to Elovich model, while the correlation coefficients of pseudo first-order kinetic model were low for both adsorbents. The kinetics data suggests that both adsorption processes obey the second order kinetics but in SDS/PS there is chemical adsorption with heterogeneous surface interaction.

Table-5: Calculated Parameter of Adsorption Kinetics

\begin{tabular}{c|c|c|c}
\hline Kinetics equation & Parameters & PS & SDS/PS \\
\hline Pseudo-first order & $\mathrm{R}^{2}$ & 0.8980 & 0.8779 \\
\cline { 2 - 4 } & $\mathrm{q}_{\mathrm{e}}$ & 71.607 & 114.05 \\
\cline { 2 - 4 } & $\mathrm{k}_{1}$ & 0.0189 & 0.0296 \\
\hline \multirow{2}{*}{ Pseudo-second order } & $\mathrm{R}^{2}$ & 0.9996 & 0.8898 \\
\cline { 2 - 4 } & $\mathrm{q}_{\mathrm{e}}$ & 13.384 & 20.498 \\
\cline { 2 - 4 } & $\mathrm{k}_{2}$ & 0.095 & 0.742 \\
\hline \multirow{2}{*}{ Elovich model } & $\mathrm{R}^{2}$ & 0.9313 & 0.9867 \\
\cline { 2 - 4 } & $\mathrm{b}_{\mathrm{E}}$ & 9.207 & 13.837 \\
\cline { 2 - 4 } & $\mathrm{a}_{\mathrm{E}}$ & 0.282 & 78.152 \\
\hline
\end{tabular}

The values of the kinetic constants of pseudo-second order and the Elovich model of both adsorbents describe that SDS modification contributes to the more intensive chemical interaction on the adsorption mechanism. The adsorption capacity, kinetics adsorption constant $\left(\mathrm{k}_{2}\right)$ from a pseudo-second order of SDS/PS is higher compared with PS. Similar pattern is also comparable in the Elovich parameters suggesting that the adsorption rate over SDS/PS is higher than PS represented by $a_{E}$, as well as the surface coverage and adsorption energy-related parameter $\left(b_{\mathrm{E}}\right)$.

\section{Flow Adsorption}

Flow adsorption experiments were also used to evaluate the capability of adsorbents. Adam-Bohart model is applied with the following equation (4):

$\frac{C_{t}}{C_{0}}=\exp \left[k_{A B} C_{0} t-k_{A B} C_{0} \frac{Z}{F}\right]$

Where, $\mathrm{Ct}$ and $\mathrm{C}_{0}$ are the concentrations of $\mathrm{RhB}$ at certain $\mathrm{t}$ and at the initial, $\mathrm{k}_{\mathrm{AB}}$ is the adsorption kinetic constant $(\mathrm{L} / \mathrm{g} / \mathrm{min}), \mathrm{N}_{0}$ is capable of adsorption $\left(\mathrm{g} \mathrm{L}^{-1}\right), \mathrm{Z}$ is the bed depth in the column $(\mathrm{m}), \mathrm{t}$ is time 
RASĀYAN $J$. Chem.

Vol. 11 | No. 3 |1166 - 1176 | July - September | 2018

(min) and $\mathrm{F}$ and the flow rate $\left(\mathrm{mL} \cdot \mathrm{min}^{-1}\right)$. The fitness of this model to the kinetics data and the kinetic parameters from flow adsorption experiments are displayed in Fig.-5.
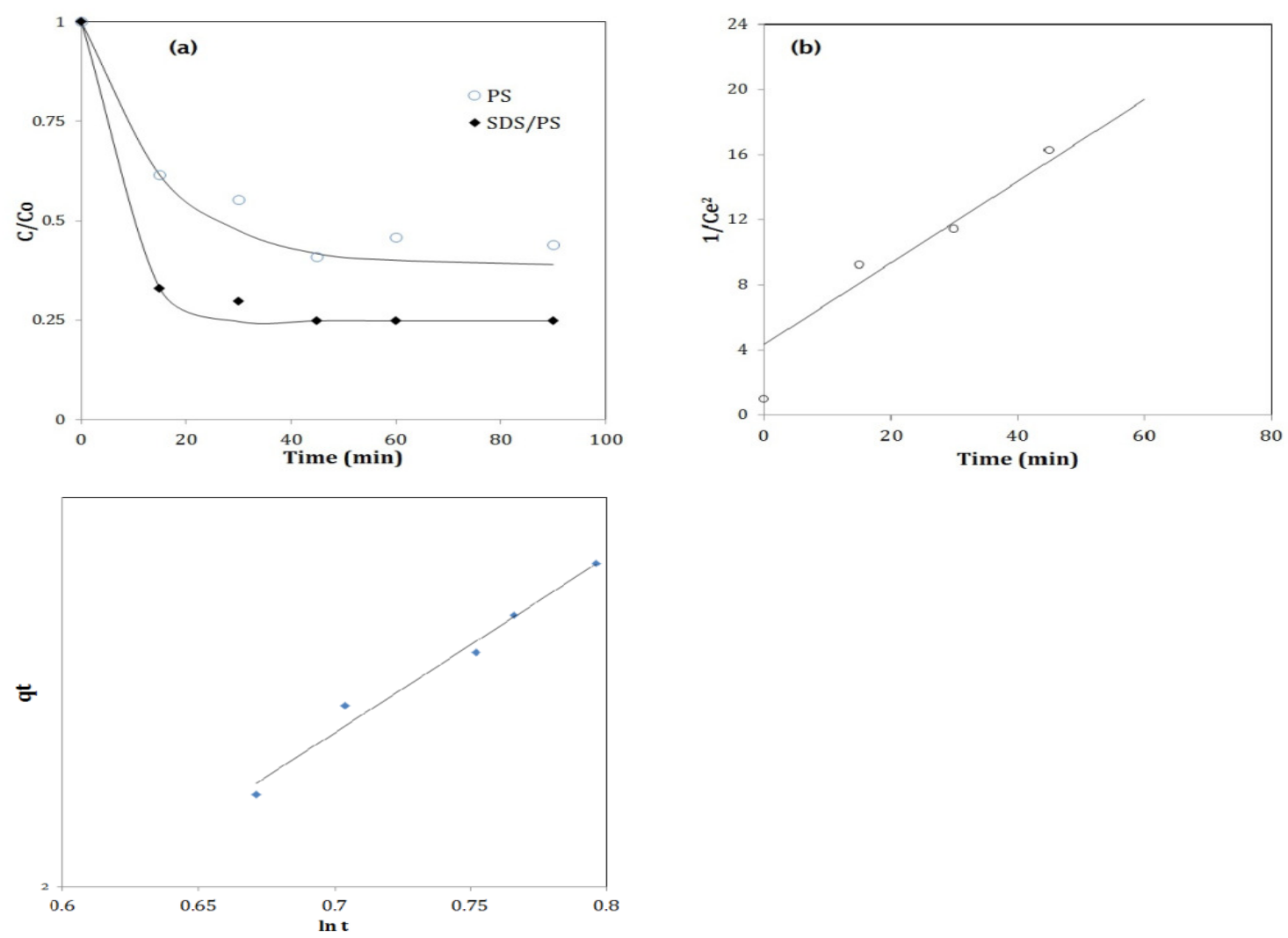

Fig.-4: (a) Kinetics Curve of RhB Adsorption using PS and SDS/PS (b) Pseudo-Second Order Plot of RhB using PS (c) Elovich Plot of RhB using SDS/PS

From the calculation, it is concluded that SDS/PS gives higher adsorption kinetics constant as an effect of a surface modification to the lignocellulosic structure of PS. The data is in line with the kinetics data representing the presence of heterogeneous interactions may occur in the adsorption interaction.

\section{Adsorption Isotherm}

The description of the correlation between adsorbed $\mathrm{RhB}$ and its equilibrium amount is studied by four isotherm models. All isotherm models were applied from the experimental data obtained in the same conditions consist of $\mathrm{RhB}$ concentration range at $5-20 \mathrm{mg} / \mathrm{L}$, an adsorbent dose of $2 \mathrm{~g} / \mathrm{l}$, the temperature of $25 \pm 1{ }^{\circ} \mathrm{C}$ and contact time of 90 mins and stirring speed $110 \mathrm{rpm}$. The fitness of the model was determined by the correlation coefficient $\mathrm{R}^{2}$ value of each plot which the higher $\mathrm{R}^{2}$ indicates the fitness of the isotherm model.

The isotherm equations are:

Langmuir Adsorption Isotherm

$\frac{1}{q_{e}}=\frac{1}{q_{m}}+\frac{1}{q_{m} K_{L} C_{e}}$

Freundlich Adsorption Isotherm

$\log q_{e}=\log K_{F}+\frac{1}{n} \log C_{e}$ 
RASĀYAN $J$. Chem.

Vol. 11 | No. 3 |1166 - 1176 | July - September | 2018
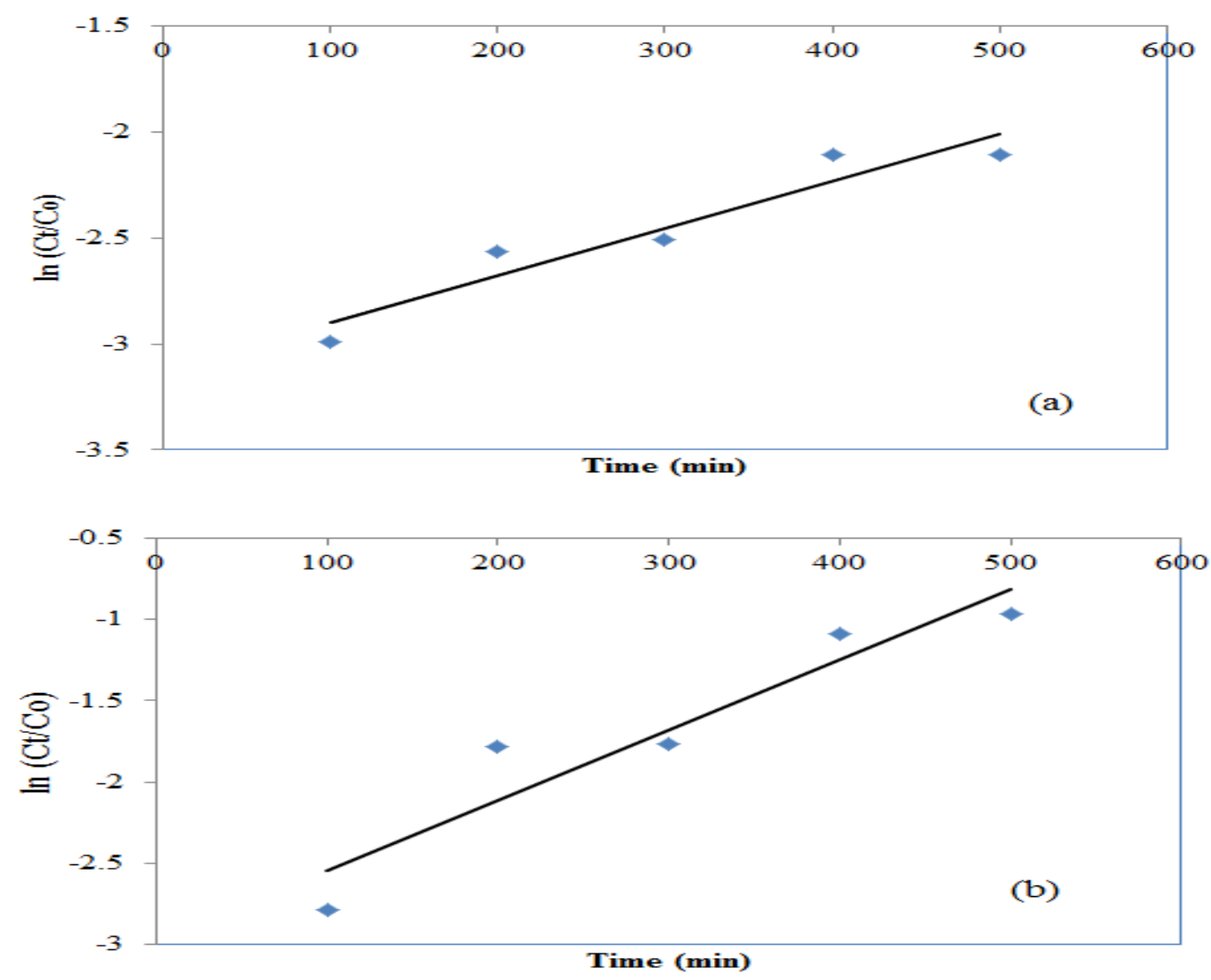

Temkin Isotherm

Fig.-5: Adam-Bohart Plot of RhB Adsorption Over (a) PS (b) SDS/PS

$q_{e}=\frac{R T}{B_{T}} \ln A_{T}+\left(\frac{R T}{B_{T}}\right) \ln C_{e}$,

and

Dubinin - Radushkevich (D-R) Isotherm Model

$\ln q_{e}=\ln q_{m}-K_{D R} \varepsilon^{2}$

Where

$\varepsilon^{2}=\left[R T \ln \left(1+\frac{1}{C_{e}}\right)\right]^{2}$

with $\mathrm{Ce}$ is concenta ration of $\mathrm{RhB}$ in equilibthe an rium state, $\mathrm{K}_{\mathrm{L}}$ is the Langmuir constant, $\mathrm{q}_{\mathrm{m}}$ is the maximum adsorption capacity, $\mathrm{K}_{\mathrm{F}}$ and $1 / \mathrm{n}$ are the Freundlich constants, $\mathrm{A}_{\mathrm{T}}$ and $\mathrm{B}_{\mathrm{T}}$ are Temkin isotherm constants, $\mathrm{R}$ is the gas constant, and $\mathrm{T}$ is the absolute temperature. From the D-R isotherm, KDR is the $\mathrm{D}-\mathrm{R}$ isotherm constant, and from the constant, the adsorption energy, $\mathrm{E}$ can be calculated based on the following equation (10):

$E=\frac{1}{\left(2 K_{D}\right)^{0.5}}$

The calculated parameters of the four models are listed in Table-6. By comparing the correlation coefficients, it can be concluded that D-R isotherm provides a good model for the adsorption by both PS and SDS/PS. The fitness of the isotherm reflects the adsorption mechanism that lay on the adsorption process on the carbonaceous pores by surface layering followed by pore filling. ${ }^{26}$ The increasing adsorption capacity by SDS attachment onto the carbonaceous system is related with the increasing surface potential energy from the surfactant. The calculated maximum adsorption capacities of PS and SDS/PS from Langmuir and D-R isotherms are 120.773, $239.955 \mathrm{mg} / \mathrm{g}, 133.146$ and $236.602 \mathrm{mg} / \mathrm{g}$, 
RASĀYAN J. Chem.

Vol. 11 | No. 3 |1166 - 1176 | July - September | 2018

respectively. The comparison of adsorption capacity of the adsorbents with another various adsorbent was given in Table-7. From the data, it can be seen that SDS/PS lay on the relatively high capacity adsorbent in relatively similar with the capacity of Dika nut and acid-treated Dika nut, as well as citric acidmodified Cornstalk.

Table-6: Calculated Parameter from Adsorption Isotherms

\begin{tabular}{c|c|c|c}
\hline \multirow{2}{*}{ Isotherm model } & \multirow{2}{*}{ Parameter } & \multicolumn{2}{|c}{ Adsorbent } \\
\cline { 2 - 4 } & & $\mathrm{PS}$ & SDS/PS \\
\hline \multirow{4}{*}{ Langmuir } & $\mathrm{qm}(\mathrm{mg} / \mathrm{g})$ & 120.773 & 239.955 \\
\cline { 2 - 4 } & $\mathrm{K}_{\mathrm{L}}(\mathrm{mg} / \mathrm{L})$ & 0.9734 & 1.518 \\
\cline { 2 - 4 } & $\mathrm{R}^{2}$ & 0.9914 & 0.9984 \\
\hline \multirow{4}{*}{ Freundlich } & $\mathrm{n}$ & 0.788 & 1.325 \\
\cline { 2 - 4 } & $\mathrm{K}_{\mathrm{L}}$ & 5.074 & 62.227 \\
\cline { 2 - 4 } & $\mathrm{R}^{2}$ & 0.9767 & 0.9998 \\
\hline \multirow{5}{*}{ Temkin } & $\mathrm{A}_{\mathrm{T}}$ & 3.116 & 57.589 \\
\cline { 2 - 4 } & $\mathrm{B}_{\mathrm{T}}$ & 3.022 & 57.353 \\
\cline { 2 - 4 } & $\mathrm{R}^{2}$ & 0.9695 & 0.9989 \\
\hline \multirow{5}{*}{$\mathrm{D}-\mathrm{R}$} & $\mathrm{qm}(\mathrm{mg} / \mathrm{g})$ & 133.146 & 236.602 \\
\cline { 2 - 4 } & $\mathrm{K}_{\mathrm{DR}}$ & 1.772 & 0.9966 \\
\cline { 2 - 4 } & $\mathrm{R}^{2}$ & 0.9993 & 4856.79 \\
\cline { 2 - 4 } & $\mathrm{E}(\mathrm{Joule} / \mathrm{mol})$ & 1703.32 & \\
\hline
\end{tabular}

Table-7: Adsorption Capacity of Biosorbent for RhB

\begin{tabular}{c|c|c}
\hline Adsorbent & $\begin{array}{c}\mathrm{qm} \text { at } \\
25^{\circ} \mathrm{C}(\mathrm{mg} / \mathrm{g})\end{array}$ & Reference \\
\hline Dika nut & 212.77 & 27 \\
\hline Acid-treated Dika nut & 232 & 27 \\
\hline Coconut shell char & $41.67 \mathrm{mg} / \mathrm{g}$ & 28 \\
\hline Chemical Modified Cornstalk & 245.6 & 29 \\
\hline Jute stick powder & $87.7 \mathrm{mg} / \mathrm{g}$ & 30 \\
\hline Raphia hookerie fruit epicarp & $666.67 \mathrm{mg} / \mathrm{g}$ & 31 \\
\hline Annona muricata L. seeds & 36 & 32 \\
\hline used black tea leaves (UBTL) & $53.2 \mathrm{mg} / \mathrm{g}$ & 33 \\
\hline Peanut shell (PS) & 133.146 & This research \\
\hline SDS/PS & 236.602 & This research \\
\hline
\end{tabular}

\section{Effect of Temperature on Adsorption}

To further understand the effect of temperature on the adsorption process by PS and SDS/PS, adsorption capacity at varied temperature was conducted, and the pattern is depicted in Fig.-6. At the range of room temperature until $50^{\circ} \mathrm{C}$, the adsorption capacity is linearly increased as increasing temperature, but it decreased at a further elevated temperature at $60^{\circ} \mathrm{C}$. A similar pattern is also reported by utilization of water algae and brown marine seaweed ${ }^{34}$. In the beginning, increasing temperature affect to activate the target molecule and surface interaction in the adsorption mechanism, but in advance, the increasing temperature affects to the surface structure which mainly contains cellulose hydrolysis. The hydrolysis destroys cellulose structure and contributes to reducing the surface interaction and force desorption.

The Gibbs free energy and van't Hoff equations were utilized to perform calculation of $\Delta \mathrm{G}, \Delta \mathrm{H}$ and $\Delta \mathrm{S}$ using the equation (10):

$\Delta G^{0}=-R T \ln \left(K_{0}\right)$

$\ln K_{0}=-\frac{\Delta G^{0}}{R T}=-\frac{\Delta H^{0}}{R T}+\frac{\Delta S^{0}}{R T}$

From the calculated parameters listed in Table- 8 , the Gibbs function $\Delta G^{0}$ values are laid at the range of -9.440 to $-5.857 \mathrm{~kJ} / \mathrm{mol}$, indicating that adsorption is mainly physisorption. The van der Waals and polar-non polar interaction among $\mathrm{RhB}$, functional groups, cellulose and surfactant may dominantly 
affect the adsorption. By comparing two adsorbents, in general, it can be seen that the $\Delta G^{0}$ of SDS/PS is more negative than PS in line with the higher entropy $\left(\Delta S^{0}\right)$ and enthalpy $\left(\Delta H^{0}\right)$. These values suggest that SDS modification contributes to enhancing adsorption mechanism. The value of entropy is negative $\Delta S^{0}$ due to decreased randomness at the solid/solution interface during adsorption of $\mathrm{RhB}$ onto adsorbent surface ${ }^{26}$.

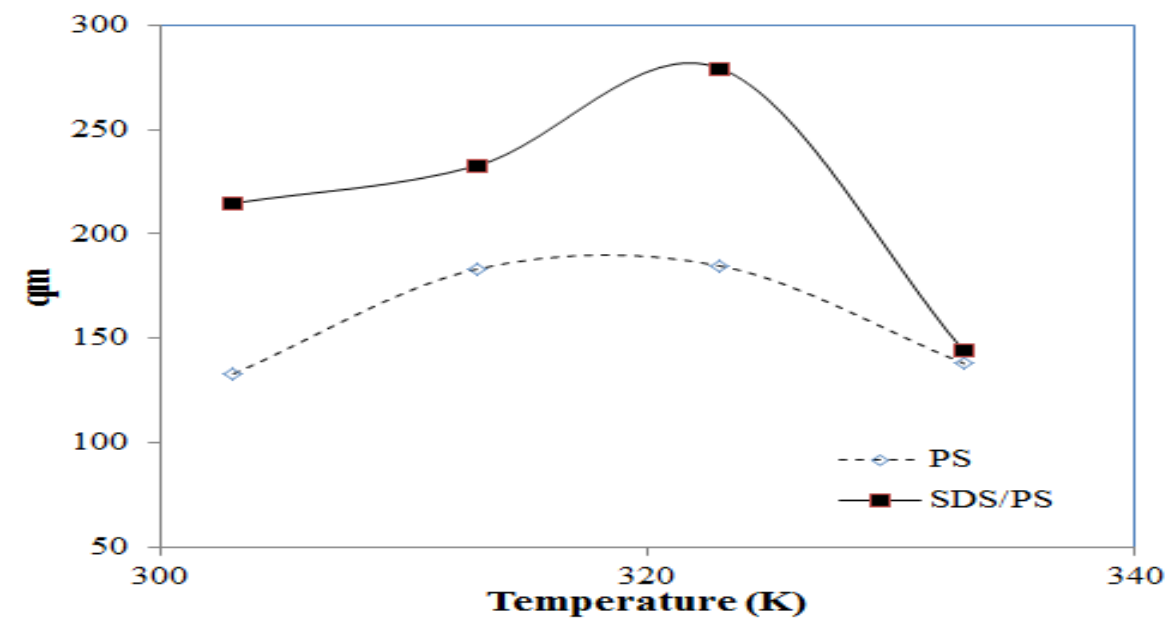

Fig.-6: Effect of Temperature on Adsorption Capacity

Table-8: Calculated Thermodynamic Parameters of Adsorption

\begin{tabular}{|c|c|c|c|c|}
\hline Adsorbent & $\mathrm{T}(\mathrm{K})$ & $\Delta \mathrm{G}^{\mathrm{o}}(\mathrm{kJ} / \mathrm{mol})$ & $\Delta \mathrm{S}^{\mathrm{o}}(\mathrm{kJ} / \mathrm{mol})$ & $\Delta \mathrm{H}^{\circ}(\mathrm{kJ} / \mathrm{mol})$ \\
\hline \multirow{4}{*}{ PS } & 303 & -6.270 & \multirow{4}{*}{-0.0617} & \multirow{4}{*}{-12.877} \\
\hline & 313 & -6.370 & & \\
\hline & 323 & -5.857 & & \\
\hline & 333 & -8.750 & & \\
\hline \multirow{4}{*}{ SDS/PS } & 303 & -7.330 & \multirow{4}{*}{-0.0459} & \multirow{4}{*}{-6.859} \\
\hline & 313 & -7.668 & & \\
\hline & 323 & -6.749 & & \\
\hline & 333 & -9.440 & & \\
\hline
\end{tabular}

\section{CONCLUSION}

This study highlighted the feasibility of surfactant-modified peanut shell (SDS/PS) for the removal of rhodamine B from aqueous solution in batch and flow mode. The increasing adsorption capacity was observed by modification of peanut with sodium dodecyl sulfate (SDS). Experimental data showed that the kinetics of adsorption over PS and SDS/PS are in better agreement with pseudo-second-order kinetic model and Elovich kinetics, respectively, meanwhile, for the flow mode of adsorption, the data are fit to the Adam-Bohart adsorption model. The determined adsorption capacities of PS and SDS/PS are 133.146 and $236.699 \mathrm{meq} / \mathrm{g}$, respectively and the isotherm refer to D-R isotherm model. The calculated adsorption thermodynamic parameters indicated that the adsorption occurs in a physisorption mechanism.

\section{ACKNOWLEDGMENT}

Authors gratefully thank Chemistry Department, Universitas Islam Indonesia for financial support of the project No: 003/ProdiKim/V/2018.

\section{REFERENCES}

1. E. Khoo and S. Ong, in 1st World Sustainability Forum (2011), pp. 1-9.

2. D.L. Postai, C.A. Demarchi, F. Zanatta, D.C.C. Melo, and C.A. Rodrigues, Alexandria Engineering Journal, (2016), DOI: 10.1016/j.aej.2016.03.017.

3. D. Sun, Z. Zhang, M. Wang, and Y. Wu, American Journal of Analytical Chemistry, 2013, 17 (2013), DOI: $10.4236 / a j a c .2013 .47$ A003.

4. I.E. Agbozu and F.O. Emoruwa, Afr. J. Environ. Sci. Technol.,8, 239 (2014), DOI:10.5897/AJEST2013.1577. 


\section{RASĀYAN J. Chem.}

Vol. 11 | No. 3 |1166 - 1176 | July - September | 2018

5. P. Thamilarasu, M. Mohan, V. Dharmalingam, R. Sharmila, and K. Karunakaran, Rasayan Journal of Chemistry, 7, 390 (2014).

6. A. Basker, P.S. Syed Shabudeen, P. Vignesh Kumar, and A.P. Shekhar, Rasayan Journal of Chemistry, 7, 64 (2014).

7. N. Kaushik, C.P. Kaushik, R. Tuteja, and J.K. Sharma, Rasayan Journal of Chemistry, 1, 819 (2008).

8. T. Santhi, S. Manonmani, T. Smitha, and K. Mahalakshmi, Rasayan Journal of Chemistry, 2, 813 (2009).

9. N. Gopal and M. Asaithambi, Rasayan Journal of Chemistry, 8, 279 (2015).

10. B.P. Statistik, Produksi Kacang Tanah Menurut Provinsi (Ton), 1993-2015 (2018).

11. S. Boumchita, A. Lahrichi, Y. Benjelloun, S. Lairini, V. Nenov, and F. Zerrouq, Journal of Materials and Environmental Science, 8, 2353 (2017).

12. L.C. Romero, A. Bonomo, E.E. Gonzo, and I. De, Investigaciones, Adsorption Science \& Technology 22, (2004).

13. X.-K. Ouyang, L.-P. Yang, and Z.-S. Wen, BioResources, 9, 2446 (2014), DOI:10.15376/biores.9.2.2446-2458.

14. K. Periasamy and C. Namasivayam, Chemosphere, 32, 769 (1996), DOI:10.1016/00456535(95)00332-0

15. T. XU and X. LIU, Chinese Journal of Chemical Engineering, 16, 401 (2008), DOI:10.1016/S10049541(08)60096-8.

16. M. Kamaraj and P. Umamaheswari, Journal of Materials and Environmental Science, 8, 2019 (2017).

17. J. Georgin, G.L. Dotto, M.A. Mazutti, and E.L. Foletto, Journal of Environmental Chemical Engineering, 4, 266 (2016), DOI:10.1016/j.jece.2015.11.018.

18. M. A Akl and A.F. M Youssef, Journal of Environmental \& Analytical Toxicology, 06, (2016), DOI:10.4172/2161-0525.1000352.

19. G.R. Geology, C. Synthesis, and C. Synthesis, RSC Advance, 5, 74467 (2015).

20. C. Namasivayam and M. V. Sureshkumar, Bioresource Technology, 99, 2218 (2008), DOI:10.1016/j.biortech.2007.05.023.

21. A.M. Yeneneh, S. Maitra, and U. Eldemerdash, Journal of Applied Sciences, 11, 3555 (2011), DOI: $10.3923 /$ jas.2011.3555.3562

22. I. Fatimah, A. Yahya, and R.A.T. Sasti, in AIP Conference Proceedings, (2017), DOI:10.1063/1.4978198.

23. B. Li, in Fourier Transform - Materials Analysis (2011), pp. 165-190, DOI:10.1016/S00086223(01)00165-8.

24. R.B. Fidel, D.A. Laird, and M.L. Thompson, Journal of Environment Quality, 42, 1771 (2013), DOI:10.3390/min7020029.

25. K. Sun, T. Liu, Y. Zhang, X. Liu, B. Wang, and C. Xu, Minerals, 7, 29 (2017).

26. R. Lafi and A. Hafiane, Journal of the Taiwan Institute of Chemical Engineers, 58, 424 (2016), DOI:10.1016/j.jtice.2015.06.035.

27. Inyibor, A. A, F.A. Adekola, and G.A. Olatunji, South African Journal of Chemistry, 68, 115 (2015), DOI:10.17159/0379-4350/2015/v68a17

28. G. Sreelatha and P. Padmaja, Journal of Environmental Protection Science, 2, 63 (2008).

29. Q.L. Cao, Y.M. Zhao, X.Y. Wei, and F. Luo, Advanced Materials Research 937, 276 (2014), DOI: 10.4028/www.scientific.net/AMR.937.276

30. G.C. Panda, S.K. Das, and A.K. Guha, Journal of Hazardous Materials, 164, 374 (2009), DOI:10.1016/j.jhazmat.2008.08.015.

31. A.A. Inyinbor, F.A. Adekola, and G.A. Olatunji, Applied Water Science, 7, 3257 (2017).

32. Z. Chaidir, F. Furqani, R. Zein, and E. Munaf, Journal of Chemical and Pharmaceutical Research, 7 (4), 879(2015).

33. M.A. Hossain and M.S. Alam, Iranian Journal of Environmental Health Science and Engineering, 9, (2012), DOI:10.1186/1735-2746-9-2.

34. S.Dewi and A.Murugappan, Journal of Engineering Science and Technology, 11, 1421 (2016)

[RJC-4021/2018] 